\title{
Fundamental Properties of Composite Board Made with Oriented Strand Board and Three Different Species of Veneer ${ }^{1}$
}

\author{
Hikma Yanti $^{2} \cdot$ Muh Yusram Massijaya $^{3}$ - Tekat Dwi Cahyono (id ${ }^{4, \dagger}$ • \\ Eka Novriyanti $^{5} \cdot$ Apri Heri Iswanto $^{6}$
}

\begin{abstract}
This research presents an improvement of the physical and mechanical properties of composite board (com-ply) made of Oriented Strand Board (OSB) coated with wood veneer of Pine (Pinus merkusii), Avocado (Persea Americana) and Mahogany (Swietenia mahogany). $1.5 \mathrm{~mm}$ thick veneers of those three wood types were adhered to the surface of OSB using two adhesive types: epoxy and isocyanate. The adhesive with the glue spread of $250 \mathrm{~g} \mathrm{~m}^{-2}$ applied using single glue line was spread and then cold pressed with the pressure of $15 \mathrm{~kg} \mathrm{~cm}^{-2}$ for 3 hours. The research result showed an improving dimension stability of com-ply, but not found on all parameters of physical property test. The moisture content seemed to be influenced by the com-ply type, yet not related to its thickness swelling, water absorption and linear expansion. The exception took place in the parallel linear expansion when immersed for 2 hours. The highest to the lowest increases of MOE and MOR were consecutively found on OSB coated with wood veneer of Pine, Mahogany and Avocado. However, the increases were statistically insignificant. The highest increasing screw hold power was found at the com-ply type AE (avocado veneer and epoxy adhesive) that was by $28 \%$.
\end{abstract}

Keywords: avocado, mahogany, OSB, com-ply, pine

\section{INTRODUCTION}

In some countries, including Indonesia, the production capacity of veneer and veneer based industries each year shows a fluctuating trend. For example, plywood production tended to decline from year to year since 1997. In 2002, the production of Indonesian plywood reached only 1.20 million $\mathrm{m}^{3}$ and continuously declined from the previous years. Furthermore, within a period of 2013-2017, the production of plywood the increase approximately reached 3.2-3.6 million $\mathrm{m}^{3}$ (PDI, 2016). Factors causing this fluctuation include lack of raw materials, government's policies, and company's internal factors. In the future, plywood industry may gradually

${ }^{1}$ Date Received December 20, 2018, Date Accepted March 12, 2019

2 Faculty of Forestry, Tanjungpura University, Pontianak, Indonesia

${ }^{3}$ Department of Forest Product, Faculty of Forestry, Bogor Agricultural University (IPB)

${ }^{4}$ Faculty of Agriculture, University of Darussalam Ambon, Ambon, Indonesia

${ }^{5}$ Research Institute of Fiber Technology of Forest Plants, FORDA, Bangkinang, Indonesia

${ }^{6}$ Department of Forest Product, Faculty of Forestry, Universitas Sumatera Utara, Padang Bulan, Medan 20155, Indonesia

$\dagger$ Corresponding author: Tekat Dwi Cahyono (e-mail: tekatdwicahyono@gmail.com, ORCID: 0000-0002-3010-7656) 
increase as there are still great potentials to develop (CDMI, 2015).

Problem due to the lack of raw materials may be anticipated with two approaches. First, extending the raw material sources by using the raw materials with smaller wood diameters (Cahyono et al., 2015; Darmawan et al., 2015; Muñoz and Moya, 2018), fast growing and less recognized wood including the planting wood waste, such as thinning and pruning (Rowell, 1998). However, these types of wood have inferior characteristics that the following approach is greatly required, that is the utilization of lignocellulose containing materials to enrich the composite wood products (composite/ compound wood) (Santoso et al., 2000). The forms of compound wood products include fiberboard, particle board, waferboard, flakeboard, oriented strand board (OSB) and com-ply (Maloney, 1977; Rowell et al., 1986; Iswanto et al., 2017; Jang et al., 2017).

Actually, engineering efforts in improvement the quality of composite board kept conducted, one of which was to add veneer layer (com-ply). This addition of veneer layer could improve OSB surface appearance (Nuryawan and Massijaya, 2005; Bowyer et al., 2007). Besides, Biblis et al. (1996) stated that the addition of veneer of OSB surface increases the value of MOE and MOR up to $117 \%$. The increases of MOE and MOR value were respectively $129.5 \%$ and $75.9 \%$, found on MDF after veneer coating with better flexural properties (Cahyono et al., 2018). Veneer coating had also been proven increasing the com-ply resistance against the subterranean and drywood termites (Iswanto et al., 2017; Cahyono et al., 2018). Those strengths might become the choice for the industrial actors of forest products industries to well maintain their products' continuity and variations. Moreover, the utilization of veneer made from less familiar wood in market, such as avocado wood and good-appearance wood as face veneer, includes pine and mahogany.

Besides color and appearance reasons, avocado, pine, and mahogany woods have good dimensional stability. The next challenge was whether the three types of wood veneer are able to improve the dimensional stability of composite board and other fundamental properties. Therefore, avocado, pine, and mahogany based veneers in this research were used for Oriented Strand Board surface coating. This research aimed at evaluating the Com-ply's fundamental properties. The research result could provide one alternative composite product utilizing wood from the community forest, supporting the resources' efficiency, yet still meeting the standard quality.

\section{MATERIALS and METHODS}

\subsection{Material preparation}

The material used in this study was the Oriented Strand Board (OSB) easily obtained from the local markets. The OSB was $1.0 \mathrm{~cm}$ thick, using strand from various types of wood and phenol formaldehyde as adhesive. The used veneer was made from pine, avocado and mahogany, respectively. The veneer was $1.5 \mathrm{~mm}$ thick and two adhesive types used in this research were isocyanate and epoxy. Isocyanate adhesive consists of base and hardener with the composition of 100:15, while the epoxy adhesive uses the composition of 100:100.

\subsection{Com-ply making}

Veneer and OSB were cut in the size of $35 \mathrm{~cm} \mathrm{x}$ $35 \mathrm{~cm}$. The moisture contents of veneer and OSB before gluing process were respectively $7 \pm 0.32 \%$ and $12 \pm$ $0.46 \%$. The adhesive was applied with the single glue spread of $250 \mathrm{~g} \mathrm{~m}^{-2}$. The activity was then followed with layer arrangement and compression. OSB was used as core while the veneer was used as face and back layer materials. The arrangement was completely presented further in Table 1. Cold compression was given for 3 hours with the pressure of $15 \mathrm{~kg} \mathrm{~cm}^{-2}$. 
Table 1. Types of OSB Composite Plywood

\begin{tabular}{clll}
\hline Num. & Type & Adhesive & $\begin{array}{l}\text { Core and } \\
\text { Back Veneer }\end{array}$ \\
\hline \hline 1 & K & - & - \\
2 & AI & Isocyanate & Avocado \\
3 & AE & Epoxy & Avocado \\
4 & PI & Isocyanate & Pine \\
5 & PE & Epoxy & Pine \\
6 & MI & Isocyanate & Mahogany \\
7 & ME & Epoxy & Mahogany \\
\hline
\end{tabular}

Before testing, the test samples were conditioned for two weeks. The conditioning was performed at room temperature $\left(25^{\circ} \mathrm{C}\right)$ and relative humidity $(\mathrm{RH})$ of $85 \%$ until the air-dry moisture content.

\subsection{Physical and mechanical testing}

In the implementation of this study, testing was conducted on some physical and mechanical properties. The physical characteristics were analyzed include density, moisture content, water absorption, thickness swelling and linear expansion. The mechanical characteristics were examined using the universal testing machine (UTM). The samples' width and length for the bending test was $5 \mathrm{~cm} \times 30 \mathrm{~cm}$, while that for internal bonding (IB) and screw hold power (SHP) was
$5 \mathrm{~cm} \times 5 \mathrm{~cm}$ and $5 \mathrm{~cm} \times 10 \mathrm{~cm}$, respectively. All measurements referred to JIS A 5908-2003 standards (JSA, 2003).

\subsection{Data analysis}

This research used the completely randomized design with 7 treatments utilizing com-ply type $\mathrm{K}, \mathrm{AI}, \mathrm{AE}$, MI, ME, PI, and PE. The common model of this design was as presented by Gaspersz (1991). If the treatment type was significant, Duncan advance test was further conducted to obtain the best combination.

\section{RESULTS and DISCUSSION}

\subsection{Density and moisture content (MC)}

OSB's density was $0.70 \mathrm{~g} \mathrm{~cm}^{-3}$ with the standard deviation of 0.03 . After the addition of veneer layers, the density increased approximately $22-28 \%$. The density of all com-ply types were presented in Fig. 1. The increasing density was due to the addition of veneer and two adhesive layers in both face and back part. As the comparative material, the density of Samama plywood increases by 11-23\% (Cahyono et al., 2017) while the density of Samama's laminated veneer lumber (LVL) had also increased when compared before the adhesion process (Cahyono et al., 2018). The specific

Table 2. Physical properties of Com-ply

\begin{tabular}{|c|c|c|c|c|c|c|c|c|c|c|}
\hline \multirow[t]{2}{*}{$\begin{array}{l}\text { Com-ply } \\
\text { Type }\end{array}$} & \multirow[t]{2}{*}{$\begin{array}{l}\text { MC } \\
(\%)\end{array}$} & \multirow[t]{2}{*}{$\begin{array}{l}\text { Density } \\
\left(\mathrm{g} \mathrm{cm}^{-3}\right)\end{array}$} & \multicolumn{2}{|c|}{$\begin{array}{c}\text { Water Absorption } \\
\text { (\%) }\end{array}$} & \multicolumn{2}{|c|}{$\begin{array}{c}\text { Thickness Swelling } \\
\text { (\%) }\end{array}$} & \multicolumn{2}{|c|}{$\begin{array}{c}\text { Parallel Linear } \\
\text { Expansion } \\
(\%) \\
\end{array}$} & \multicolumn{2}{|c|}{$\begin{array}{l}\text { Perpendicular Linear } \\
\text { Expansion } \\
(\%) \\
\end{array}$} \\
\hline & & & 2 Hour & 24 Hour & 2 Hour & 24 Hour & 2 Hour & 24 Hour & 2 Hour & 24 Hour \\
\hline K & $13.41 \pm 0.44$ & $0.70 \pm 0.03$ & $12.36 \pm 3.20$ & $31.76 \pm 8.48$ & $2.30 \pm 0.98$ & $8.59 \pm 2.93$ & $0.38 \pm 0.12$ & $0.57 \pm 0.07$ & $0.44 \pm 0.05$ & $0.68 \pm 0.08$ \\
\hline MI & $14.65 \pm 0.64$ & $0.86 \pm 0.02$ & $14.62 \pm 3.03$ & $43.70 \pm 8.81$ & $3.24 \pm 1.26$ & $8.69 \pm 1.69$ & $0.31 \pm 0.08$ & $0.50 \pm 0.14$ & $0.44 \pm 0.13$ & $0.73 \pm 0.12$ \\
\hline ME & $12.76 \pm 0.20$ & $0.91 \pm 0.03$ & $11.58 \pm 3.43$ & $30.06 \pm 8.12$ & $1.50 \pm 0.61$ & $5.43 \pm 1.97$ & $0.16 \pm 0.06$ & $0.48 \pm 0.13$ & $0.37 \pm 0.15$ & $0.65 \pm 0.13$ \\
\hline AI & $13.72 \pm 0.25$ & $0.93 \pm 0.05$ & $13.29 \pm 2.90$ & $31.31 \pm 5.36$ & $1.67 \pm 0.42$ & $5.31 \pm 0.84$ & $0.21 \pm 0.06$ & $0.59 \pm 0.15$ & $0.26 \pm 0.05$ & $0.70 \pm 0.15$ \\
\hline $\mathrm{AE}$ & $13.52 \pm 0.43$ & $0.91 \pm 0.03$ & $12.51 \pm 1.55$ & $36.15 \pm 7.75$ & $1.75 \pm 0.62$ & $7.08 \pm 2.15$ & $0.26 \pm 0.14$ & $0.50 \pm 0.16$ & $0.35 \pm 0.11$ & $0.60 \pm 0.19$ \\
\hline PI & $14.56 \pm 2.09$ & $0.95 \pm 0.07$ & $11.45 \pm 6.50$ & $23.28 \pm 8.53$ & $1.98 \pm 1.43$ & $5.36 \pm 3.25$ & $0.14 \pm 0.11$ & $0.41 \pm 0.23$ & $0.30 \pm 0.17$ & $0.62 \pm 0.32$ \\
\hline PE & $13.33 \pm 0.33$ & $0.99 \pm 0.05$ & $12.84 \pm 3.26$ & $32.59 \pm 9.99$ & $2.52 \pm 1.06$ & $7.84 \pm 1.35$ & $0.22 \pm 0.08$ & $0.44 \pm 0.06$ & $0.35 \pm 0.13$ & $0.61 \pm 0.07$ \\
\hline
\end{tabular}


Table 3. Summary of ANOVA based on Com-ply's physical characteristics

\begin{tabular}{lcc}
\hline Dependent Variable & F & $\begin{array}{c}\text { Signifi } \\
\text { cance }\end{array}$ \\
\hline \hline MC & 3.27 & 0.015 \\
Density & 18.47 & 0.000 \\
Water Absorption (2 Hours) & 0.35 & 0.907 \\
Water Absorption (24 Hours) & 1.84 & 0.127 \\
Thickness Swelling (2 Hours) & 1.55 & 0.200 \\
Thickness Swelling (24 Hours) & 1.98 & 0.103 \\
Parallel Linear Expansion (2 Hours) & 2.91 & 0.025 \\
Parallel Linear Expansion (24 Hours) & 0.82 & 0.564 \\
Perpendicular Linear Expansion & 1.25 & 0.313 \\
(2 Hours) & & \\
Perpendicular Linear Expansion & 0.34 & 0.909 \\
(24 Hours) & & \\
\hline
\end{tabular}

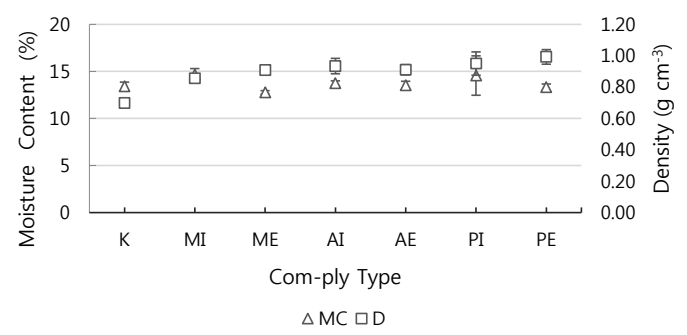

Fig. 1. Moisture Content and Density of all Com-ply Types.

gravity of Samama is $0.39-0.59$ and after made into LVL product, its specific gravity ranged from $0.45-0.51$ (Cahyono et al., 2016; Cahyono et al., 2018). In addition, Cristescu (2006) explained that the increasing density was due to the veneer's physical and anatomical changes at the adhesion areas. This statement was strengthened with the result of ANOVA explaining that com-ply type influences its density (Table 3 ).

The further Duncan Test showed that the com-ply which outside layers was made from pine veneer and epoxy adhesive (type PE) had the highest density. Meanwhile, OSB without veneer layer (type K) was at the lowest level (Table 4). The size of pine's fiber wall was twice thicker than that of mahogany's
Table 4. Duncan Analysis on Density

\begin{tabular}{|c|c|c|c|c|c|}
\hline \multirow{2}{*}{ Type } & \multirow{2}{*}{$\mathrm{N}$} & \multicolumn{4}{|c|}{ Subset } \\
\hline & & 1 & 2 & 3 & 4 \\
\hline $\mathrm{K}$ & 5 & .6980 & & & \\
\hline MI & 5 & & .8560 & & \\
\hline $\mathrm{ME}$ & 5 & & .9080 & .9080 & \\
\hline $\mathrm{AE}$ & 5 & & .9100 & .9100 & \\
\hline AI & 5 & & & .9340 & .9340 \\
\hline PI & 5 & & & .9440 & .9440 \\
\hline $\mathrm{PE}$ & 5 & & & & .9920 \\
\hline Significance & & 1.000 & .112 & .302 & .089 \\
\hline
\end{tabular}

(Karlinasari et al., 2010). This was one of the causes why pine had the highest density when compared to the other two wood types. Tsoumis (1991) explained that the wood density values varied due to the fiber wall's thickness differences. Thick fiber wall with a small lumen had a high density, while thin fiber wall with a thick lumen had a low density. The fiber wall thickness also influenced the stability of wood dimension and moisture content.

OSB's moisture content was $13.41 \pm 0.44 \%$, while the average moisture content of those 6 com-ply types (AI, $\mathrm{AE}, \mathrm{PI}, \mathrm{PE}, \mathrm{MI}, \mathrm{ME}$ ) was higher, that was, $13.66 \pm 1.01 \%$. This value was classified into high category because JIS standard only required the moisture content of less than $13 \%$. This was due to the measurement made when there was a consistent increase of moisture content after made into com-ply as type PE and ME had KA lower than type $\mathrm{K}$ does. The other types had higher MC. The result of ANOVA showed that com-ply type influenced moisture content (Table 3). The further Duncan test showed that com-ply type PI (pine veneer and isocyanate adhesive) had the highest moisture content. 


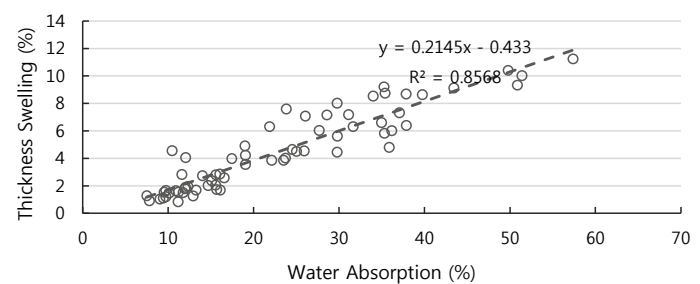

Fig. 2. Thickness swelling (TS) based on water absorption (WA) changes.

\subsection{Water absorption, thickness swelling and linear expansion}

Table 2 showed the value of water absorption (WA), thickness swelling (TS) and linear expansion (LE) of all com-ply types. There was no clear trend shown between com-ply and OSB, which values were, some, bigger and, the others were smaller than type K. Com-ply type PI (pine veneer, isosianat adhesive) had smaller value of OSB and consistent at almost all variables. Although the difference reached $38 \%$ on thickness swelling of 24 hours, yet the value was not statistically significant. It was proven by the result of ANOVA which was not significant (Table 3). From eight dimension stabilization indicator variables, only parallel linear expansion statistically influenced when measured after the immersion of two hours. The analytical result of Duncan test showed that this variable made OSB had the biggest value when compared with all com-ply types.

The dimension stabilization indicator was closely related each other due to the addition of panel moisture content which could increase the thickness swelling and linear expansion. The other opinion states that moisture change was one main cause of linear expansion change when compared to the moisture content itself ( $\mathrm{Wu}$ and Suchsland, 1996). Fig. 2 showed the regression between thickness swelling and water absorption. The undertaking relationship was linear with the formula $T S=0.2145 W A-0.433$. The determination's coefficient value 0.8568 showed that both variables influence each other. Unlike TS, the relationship between LE and WA

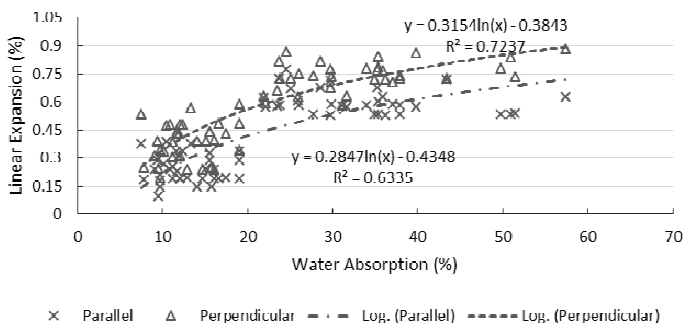

Fig. 3. Linear Expansion based on Water Absorption changes.

was logarithmic with the formula presented in Fig. 3. The determination's coefficient is 0.6335 for parallel direction and 0.7237 for perpendicular direction. Those values were classified into high category to explain the influence between LE and WA.

Linear expansion with perpendicular direction was more consistent when compared to parallel direction. The difference was shown at the trend line of Fig. 3. This was found in both OSB and com-ply, as well as shown in variables of immersion for 2 hours and 24 hours. The value difference varied from $1 \%$ to $62 \%$. The result $t$ test asserted that the value difference between parallel and perpendicular direction with the value of $p \leq 1 \%$. The supporting research result was obtained from that conducted by $\mathrm{Wu}$ and Suchsland (1996) stating that LE with perpendicular direction was bigger than that with parallel direction.

\subsection{Modulus of elasticity (MOE) and modulus of rupture (MOR)}

The tested mechanical characteristics in this research were flexural properties (MOE, MOR), Screw Hold Power (SHP) and Internal Bonding (IB). Fig. 4 showed the value of flexural properties of all com-ply types. Type K had MOE of $9832 \pm 3946 \mathrm{~N} \mathrm{~mm}^{-2}$. The other com-ply types tended to have smaller values than type K. Moreover, type AI (avocado veneer, isocyanate adhesive) had the difference up to $48 \%$ with OSB. Meanwhile, the value of MOR type K was $38 \pm 14 \mathrm{~N}$ 
Table 5. Summary of ANOVA based on Mechanical Characteristics

\begin{tabular}{lcc}
\hline Dependent Variable & F & Sig. \\
\hline \hline MOE & 1.98 & 0.102 \\
MOR & 0.68 & 0.663 \\
Screw Hold Power & 3.27 & 0.015 \\
Internal Bonding & 0.81 & 0.571 \\
\hline
\end{tabular}

$\mathrm{mm}^{-2}$ and considered relatively low when compared to all com-ply types. The com-ply with the lowest MOR was AI while the highest was PE type (pine veneer, Epoxy adhesive) of $47 \pm 10 \mathrm{~N} \mathrm{~mm}^{-2}$ (23\% higher than type K). The result of ANOVA showed that the com-ply type made in this research did not influence the value of flexural properties (Table 5). It showed that this research had found value differences of MOE and MOR between OSB and OSB coated with veneer. However, the difference was not significant.

The difference in MOE of composite board could be explained using two approaches. First, OSB density and com-ply density. Improving OSB and Com-ply density could improve the flexural properties. Second, different density between face, core and back layers of board (Subiyanto et al., 2008). Coating surface with materials with higher density could potentially improve board's MOE value (Biblis; Grigoriou and Carino, 1996; Sugiri et al., 2016). However, if the surface layer had lower MOE value than that of OSB, the effect was likely to be the opposite. The research result showed that MOE improvement as presented in Fig. 4 seemed to take place only because of difference in adhesive and type of veneer, but was not identical to a density improvement of com-ply as a whole. This confirmed that addition of veneer layer improves density, but the bending strength was determined by the MOE of veneer layer.

The Oriented Strand Board from sentang wood (Melia Excelsa Jack) (density $=0.58-0.6 \mathrm{~g} \mathrm{~cm}^{-3}$ ) explained by Iswanto et al. (2010) has MOE and MOR of 60100 $\mathrm{kg} \mathrm{cm}{ }^{-2}$ and $440 \mathrm{~kg} \mathrm{~cm}^{-2}$ respectively. The research

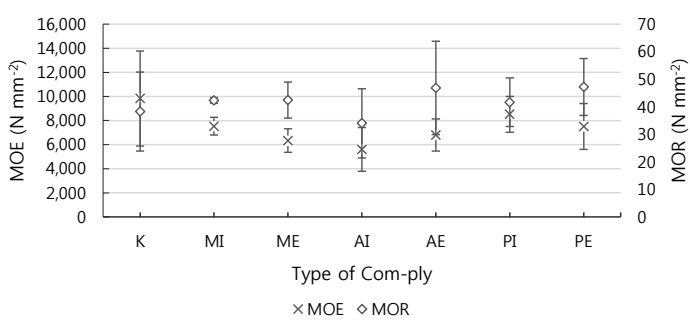

Fig. 4. MOE and MOR of all Com-ply types.

conducted by Cahyono et al. (2014) states that Bamboo Composite Beam (Specific Gravity= 0.71) had the value of MOE and MOR of $7.93 \mathrm{GPa}$ and $41.3 \mathrm{MPa}$ respectively. When compared to some previous researches, the MOE and MOR values presented in Fig. 4 showed that this product could be potentially used to improve OSB appearance and its mechanical properties.

\subsection{Screw hold power}

Com-ply is commonly used as a construction material and furniture complementary. Thus, in its utilization, com-ply will be assembled with the other materials. Celebi and Kilic (2007) stated that screw was the most frequently used material in its assembly. Data of screw hold power (SHP) were necessary to be presented in this research to support the objective. The OSB's and com-ply's Screw Hold Powers were presented in Fig. 5. The average OSB's SHP was $789 \mathrm{~N}$ with the deviation standard of $57 \mathrm{~N}$. Two com-ply types with the average of under OSB average included type PE and AI respectively by $680 \pm 139 \mathrm{~N} \mathrm{~cm}^{-2}$ and $751 \pm 111 \mathrm{~N}$. The result of ANOVA showed that com-ply type influenced SHP (Table 6). The result of further Duncan test showed

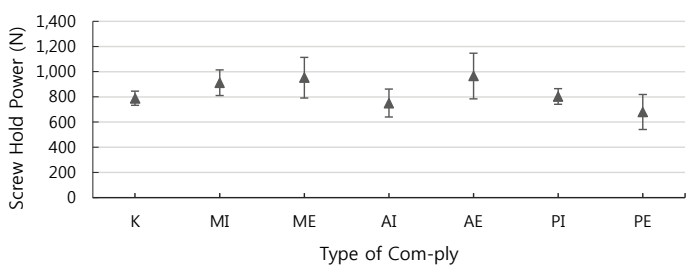

Fig. 5. Screw Hold Power of all Com-ply types. 
Table 6. Duncan Test based on Screw Hold Power

\begin{tabular}{|c|c|c|c|c|}
\hline \multirow{2}{*}{ Type } & \multirow{2}{*}{$\mathrm{N}$} & \multicolumn{3}{|c|}{ Subset } \\
\hline & & 1 & 2 & 3 \\
\hline $\mathrm{PE}$ & 5 & 51.0880 & & \\
\hline AI & 5 & 56.4460 & 56.4460 & \\
\hline $\mathrm{K}$ & 5 & 59.2777 & 59.2777 & 59.2777 \\
\hline PI & 5 & 60.3720 & 60.3720 & 60.3720 \\
\hline MI & 5 & & 68.5160 & 68.5160 \\
\hline ME & 5 & & & 71.5700 \\
\hline $\mathrm{AE}$ & 5 & & & 72.5300 \\
\hline Sig. & & .209 & .104 & .081 \\
\hline
\end{tabular}

Means for groups in homogeneous subsets are displayed. Based on observed means.

The error term is Mean Square (Error) $=108.505$.

that com-ply type $\mathrm{AE}$ and $\mathrm{ME}$ rank the highest. Both types' SHP value increased of $20-23 \%$ compared to type $\mathrm{K}$. This result also indicated that avocado and mahogany veneer, could not only change the OSB's appearance, but also had the potential to increase SHP.

The previous research concerning on OSB's SHP had been conducted by Ibrahim and Febrianto (2013). The highest SHP value presented was $70.83 \mathrm{~kg} \mathrm{~cm}^{-2}$, while the smallest was $40.9 \mathrm{~kg} \mathrm{~cm}^{-2}$. Meanwhile, for veneer-based products, LVL poplar (veneer of $5 \mathrm{~mm}$, 10 layers) had the highest SHP by $87226 \mathrm{~kg} \mathrm{~cm}^{-2}$ (Celebi and Kilic, 2007). The difference of both SHP values was greatly significant due to the different method and material used. This explanation was only used as the comparison to SHP Com-ply which OSB and veneer part were combined in one product. The difference of SHP value was influenced by the tree type which material, moisture content, orientation of grains and sections, specific gravity, rising duration, nailing method and surface smoothness are produced (Soltis, 1999).

\subsection{Internal bonding}

The com-ply's average Internal bonding (IB) was $0.35 \mathrm{~N} \mathrm{~mm}^{-2}$ with the deviation standard of $0.12 \mathrm{~N}$ $\mathrm{mm}^{-2}$. The value of IB OSB was $0.42 \pm 0.14 \mathrm{~N} \mathrm{~mm}^{-2}$.

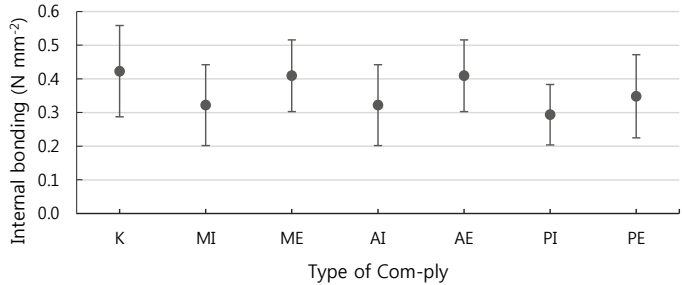

Fig. 6. Internal Bonding of all Com-ply types.

The com-ply type PI had the lowest IB value of $0.29 \pm 0.09 \mathrm{~N} \mathrm{~mm}^{-2}$ (Fig. 6). The result of ANOVA showed that com-ply type did not influence IB. This was because when testing IB, the damaging part was the middle part consisting of OSB with similar characteristics.

The internal bonding of pine's OSB presented by Cloutier et al. (2007) was $6.79 \pm 1.52 \mathrm{~kg} \mathrm{~cm}^{-2}$ and $5.42 \pm 1.02 \mathrm{~kg} \mathrm{~cm}^{-2}$ respectively for the strand radial and tangential direction. The Oriented Strand Board from Africa wood (Maesopsis eminii) and Akasia (Acacia mangium) was approximately between 3.94$7.01 \mathrm{~kg} \mathrm{~cm}^{-2}$ (Nurhaida et al., 2008). Furthermore, for Bamboo's OSB, Febrianto et al. (2012) state that the average IB was approximately between $5.41-7.28 \mathrm{~kg}$ $\mathrm{cm}^{-2}$. Based on some aforementioned IB values, the IB presented in Table 6 had lower value. However, when compared to the required standard, the minimum IB was $0.3 \mathrm{~N} \mathrm{~mm}^{-2}$, that all OSB and com-ply in this research met to JIS A 5908-2003 standard.

\section{CONCLUSION}

The conclusion may be drawn from this research is as follows:

1. Layer addition on both OSB surfaces using pine, avocado and mahogany veneer increased the density of com-ply at approximately $22-28 \%$.

2. Veneer coating was proven increasing com-ply's dimensional stability, including the Parallel Linear Expansion value during the two-hour immersion. 
3. Parallel Linear expansion was smaller when compared to the perpendicular. The value different was approximately $1-62 \%$.

4. Com-ply PE type (pine veneer, Epoxy adhesive) had MOR value 23\% higher than that of OSB. An improvement of MOE was also found as the result of veneer coating and adhesive addition, although it was statistically insignificant.

5. Com-ply type AE (avocado veneer, epoxy adhesive) had the highest value of screw hold power.

\section{REFERENCES}

Biblis, E.J., Grigoriou, A., Carino, H. 1996. Flexural properties of veneer-overlaid OSB composite panels from southern yellow pine. Forest Products Journal 46(4): 59-62.

Bowyer, J.L., Shmulsky, R., Haygreen, J.G. 2007. Forest products and wood science: an introduction. Wiley-Blackwell Publishing.

Cahyono, T.D., Darmawan, W., Novriyanti, E. 2018. Performance of LVL samama (Anthocephalus macrophyllus) based on thickness, juvenile proportion and veneer lay-up. 2018 Conference Proceedings of The Korean Society of Wood Science \& Technology 2018(1): 44-44.

Cahyono, T.D., Darmawan, W., Novriyanti, E. 2018. Performance of samama (Anthocephalus macrophyllus) LVL based on veneer thickness, juvenile proportion and lay-up. Wood Material Science \& Engineering: 1-8.

Cahyono, T.D., Massijaya, M.Y., Iswanto, A.H., Yanti, H., Annisah, L.N. 2018. The flexural properties of medium density fibreboard overlaid with veneer from three species of wood. Humanosphere Science School 2017 \& The 7th International Symposium for a Sustainable Humanosphere, Medan(ID).

Cahyono, T.D., Novriyanti, E., Bahtiar, E.T., Massijaya, M.Y. 2014. Development of composite beams made from tali (Gigantochloa apus) and hitam bamboo (Gigantochloa atroviolacea). Journal of the Indian Academy of Wood Science 11(2): 156-161.

Cahyono, T.D., Wahyudi, I., Priadi, T., Febrianto, F. 2017. Kualitas Kayu Lapis dari Finir Bagian Juvenil dan Dewasa Samama (Anthocephalus macrophyllus) (The Quality of Plywood Made from Juvenile and Mature Wood Veneer of Samama (Anthocephalus macrophyllus)). Jurnal Ilmu dan Teknologi Kayu Tropis (Journal of Tropical Wood Science and Technology) 15(2): 155-166.

Cahyono, T.D., Wahyudi, I., Priadi, T., Febrianto, F., Bahtiar, E.T., Novriyanti, E. 2016. Analysis on Wood Quality, Geometry Factor, and Their Effects on Lathe Check of Samama (Anthocephalus macrophyllus) Veneer. Journal of the Korean Wood Science and Technology 44(2): 828-841.

Cahyono, T.D., Wahyudi, I., Priadi, T., Febrianto, F., Darmawan, W., Bahtiar, E.T., Ohorella, S., Novriyanti, E. 2015. The quality of 8 and 10 years old samama wood (Anthocephalus macrophyllus). Journal of the Indian Academy of Wood Science 12(1): 22-28.

Cahyono, T.D., Yanti, H., Massijaya, M.Y., Iswanto, A.H., Uluputty, M.R. 2018. The durability of OSB Composite Plywood with Avocado, Mahogany and Pine Wood veneers against drywood and subterranean termites. International Conference on Agricultural, Environmental, and Food Security (AEFS), Medan(ID).

CDMI 2015. Studi Potensi Bisnis dan Pelaku Utama Industri Plywood (Study on Business Potential and Major Players of Plywood Industry in Indonesia). CDMI (Creative Data Make Investigation and Reasearch) Consulting Group, Jakarta(ID).

Celebi, G., Kilic, M. 2007. Nail and screw withdrawal strength of laminated veneer lumber made up hardwood and softwood layers. Construction and Building Materials 21(4): 894-900. 
Cloutier, A., Ananias, R.A., Ballerini, A., Pecho, R. 2007. Effect of radiata pine juvenile wood on the physical and mechanical properties of oriented strandboard. Holz als Roh-und Werkstoff 65(2): 157-162.

Cristescu, C. 2006. Bonding of laminated veneers with heat and pressure only. International Conference on Environmentally-Compatible Forest Products: 20/09/2006-22/09/2006, Fernando Pessoa University.

Darmawan, W., Nandika, D., Massijaya, Y., Kabe, A., Rahayu, I., Denaud, L., Ozarska, B. 2015. Lathe check characteristics of fast growing sengon veneers and their effect on LVL glue-bond and bending strength. Journal of Materials Processing Technology 215: 181-188.

Febrianto, F., Hidayat, W., Bakar, E.S., Kwon, G.-J., Kwon, J.-H., Hong, S.-I., Kim, N.-H. 2012. Properties of oriented strand board made from Betung bamboo (Dendrocalamus asper (Schultes. f) Backer ex Heyne). Wood science and technology 46(1-3): 53-62.

Gaspersz, V. 1991. Metode Perancangan Percobaan Untuk Ilmu-Ilmu Pertanian, Ilmu-Ilmu Teknik, dan Biologi. CV. Armico, Bandung, Indonesia.

Ibrahim, M.A., Febrianto, F. 2013. Properties of oriented strand board (OSB) made from mixing bamboo. Thesis, Bogor Agricultural University, Bogor(ID). Iswanto, A., Febrianto, F., Wahyudi, I., Hwang, W.-J., Lee, S.-H., Kwon, J.-H., Kwon, S.-M., Kim, N.-H., Kondo, T. 2010. Effect of pre-treatment techniques on physical, mechanical and durability properties of oriendted strandboard made from sentang wood (Melia excelsa Jack). Journal of Faculty of Agriculture Kyushu University 55(2): 371-377. Iswanto, A.H., Aritonang, W., Azhar, I., Fatriasari, W. 2017. The physical, mechanical and durability properties of sorghum bagasse particleboard by layering surface treatment. Journal of the Indian Academy of Wood Science 14(1): 1-8.
Iswanto, A.H., Simarmata, J., Fatriasari, W., Azhar, I., Sucipto, T., Hartono, R. 2017. Physical and Mechanical Properties of Three-layer Particleboards Bonded With UF and UMF Adhesives. Journal of the Korean Wood Science and Technology 45(6): 787-796.

Jang, J.-H., Lee, M., Kan, E.-C., Lee, S.-M. 2017. Characteristics of Low Density Fiberboards for Insulation Material with Different Adhesives (I) - Thermal Insulation Performance and Physical Properties -. Journal of the Korean Wood Science and Technology 45(3): 360-367.

JSA 2003. Japanese Industrial Standards (JIS) A 5908-2003: Particleboard. Japanese Standard Association (JSA), Tokyo(JP).

Karlinasari, L., Nawawi, D., Widyani, M. 2010. Kajian Sifat Anatomi dan Kimia Kayu Kaitannya dengan Sifat Akustik Kayu. Bionatura 12(3): 110-116.

Maloney, T.M. 1977. Modern particleboard and dry-process fiberboard manufacturing.

Muñoz, F., Moya, R. 2018. Effect of nanoclay-treated UF resin on the physical and mechanical properties of plywood manufactured with wood from tropical fast growth plantations. Maderas. Ciencia y tecnología 20(1): 11-24.

Nurhaida, N., Nugroho, N., Hermawan, D. 2008. Karakteristik Oriented Strand Board dari Kayu Akasia dan Afrika Berdasarkan Penyusunan Arah Strand. Jurnal Ilmu Pertanian Indonesia 13(1): 13-20.

Nuryawan, A., Massijaya, M. 2005. Development on Exterior Composite Plywood (Com-Ply) Product Made of Meranti Veneer and Ekaliptus. Peronema Forestry Science Journal 1(2): 50-54.

PDI 2016. Statistik Lingkungan Hidup dan Kehutanan Tahun 2016 (Environment and Forestry Statistic 2016). Pusat Data dan Informasi (PDI) (Data and Information Center). Ministry of Environment and Forestry of The Republic of Indonesia, Jakarta(ID). 
Rowell, R.M. 1998. The state of art and future development of bio-based composite science and technology towards the 21st century. Proceedings, 4th Pacific rim bio-based composite symposium.

Rowell, R.M., Tillman, A.-M., Simonson, R. 1986. A simplified procedure for the acetylation of hardwood and softwood flaxes for flakeboard production. Journal of Wood Chemistry and Technology 6(3): 427-448.

Santoso, A., Hadjib, N., Sutigno, P. 2000. Peningkatan mutu kayu melalui produk perekatan. Diskusi Peningkatan Kualitas Kayu. Pusat Penelitian Hasil Hutan Departemen Kehutanan dan Perkebunan, Bogor(ID).

Soltis, A.L. 1999. Wood handbook: wood as an engineering material. General Technical Report FPL-GTR-113. US Department of Agriculture, Forest Service, Forest Products Laboratory, Madison (WI).
Subiyanto, B., Rasyid, E., Gopar, M., Firmanti, A. 2008. Veneer and thin plywood overlaid for quality improvement of particleboard made of palm oil empty fruit bunches (EFB). Jurnal Ilmu dan Teknologi Kayu Tropis 6(1): 17-20.

Sugiri, S., Alamsyah, E. M., Usman, A. P. 2016. Potential of Reinforced Indonesian Glulam Beams Using Grade I (Bengkirai), Grade II (Kamper), Grade III (Nyatoh) Woods for Use in Structural Wood Design. Journal of Engineering and Technological Sciences 48(2): 150-158.

Tsoumis, G. 1991. Science and technology of wood. Structure, properties, utilization. Van Nostrand Reinhold, New York, USA.

Wu, Q., Suchsland, O. 1996. Linear expansion and its relationship to moisture content change for commercial oriented strandboards. Forest Products Journal 46(11/12): 79. 